\title{
Acute and Reproductive Toxicity of the Aqueous Extract of the Dry Seeds of Aframomum daniellii on the Female Wistar Rat Strain
}

\author{
Zacharie Nde, Modeste Wankeu-Nya, Brice L. Koloko, Sylvin B. Ateba, Marie I. Ngaha, \\ Emma F. Bend, Paul V. G. Mboumwa, Doriane C. Nyonseu Nzeubang, \\ Dieudonné Massoma Lembè
}

Laboratory of Biology and Physiology of Animal Organisms, Faculty of Sciences of Douala University, Douala, Cameroon Email: *pmasso@yahoo.fr

How to cite this paper: Nde, Z., Wankeu-Nya, M., Koloko, B.L., Ateba, S.B., Ngaha, M.I., Bend, E.F., Mboumwa, P.V.G., Nzeubang, D.C.N. and Lembè, D.M. (2021) Acute and Reproductive Toxicity of the Aqueous Extract of the Dry Seeds of Aframomum daniellii on the Female Wistar Rat Strain. Pharmacology \& Pharmacy, 12, 141-153. https://doi.org/10.4236/pp.2021.127013

Received: May 12, 2021

Accepted: July 24, 2021

Published: July 27, 2021

Copyright (C) 2021 by author(s) and Scientific Research Publishing Inc. This work is licensed under the Creative Commons Attribution International License (CC BY 4.0).

http://creativecommons.org/licenses/by/4.0/

\begin{abstract}
This work was designed to investigate the acute and reproductive toxicity activity of the aqueous extract of the dry seeds of Aframomum daniellii on the female rats. The acute toxicity of the aqueous extract of Aframomum daniellii ( $A$. daniellii) was evaluated with 6 female rats which were divided into 2 groups ( 1 Test group and the Control group) of 3 female rats each. The control group received distilled water $(10 \mathrm{~mL} / \mathrm{kg} / \mathrm{po})$ and the test group received a single dose of extract of $A$. daniellii at the dose of $2000 \mathrm{mg} / \mathrm{kg}$. The reproductive toxicity was evaluated using 45 adult female rats which were divided into 5 groups. Group I, received distilled water $(1 \mathrm{~mL} / 100 \mathrm{~g} / p o$, neutral control); group II, received Clomiphene citrate $(600 \mu \mathrm{g} / \mathrm{kg} / p o$, positive control); Groups III, IV and V (trials) received aqueous extract of $A$. daniellii at doses of 100, 200 and $400 \mathrm{mg} / \mathrm{kg} /$ po respectively. The animals were treated daily for 14 days. From the $6^{\text {th }}$ day of treatment, the rats were mated with males of proven fertility for 8 days. On day 22, after laparotomy and delivery, the number of implantation sites, corpora lutea, resorption sites and pups were recorded. Concerning the acute toxicity, it was observed that, after the single dose of $2000 \mathrm{mg} / \mathrm{kg}$ administration of the aqueous extract of the dry seeds of $A$. daniellii, no deaths were recorded. Concerning the reproductive toxicity, no implantation and gestation were observed when compared to the control. However, the aqueous extract of $A$. daniellii caused a significant ( $\mathrm{p}<$ 0.001 ) increase in serum estrogen levels in all treated rats when compared to the control. These results indicate that, the aqueous extract of the dry seeds of $A$ daniellii is weakly toxic, but could negatively affect some reproductive parameters.
\end{abstract}




\section{Keywords}

Acute Toxicity, Reproductive Toxicity, Female Rats, Aframomum daniellii

\section{Introduction}

Aframomum daniellii is a species from the large humid forests of Central Africa. It is a plant which, by rustling the leaves or rhizomes, gives off a very peculiar aromatic odor. It is a plant found in West and Central Africa (Cameroon, Gabon, Guinea, southern Nigeria) [1] [2]. The leaves are used as aromatics in meals. The fruits are edible and may have laxative properties. The seeds are used as a spice for "yellow sauce" in western Cameroon [3]. Several species of the genus Aframomum (Aframomum malégueta, Aframomum aulacocorpus, Aframomum citratum) [4] [5] have traditionally been renowned for centuries for their powerful antioxidant, aphrodisiac and vasodilator properties [4] [5] [6]. The seeds Aframomum are used in the Cameroonian pharmacopoeia in the treatment of many pathologies including sexual dysfunction [4] [6]. Phytochemical studies carried out on Aframomum daniellii have identified steroids, saponins, tannins, vitamins A, C and E, flavonoids, essential amino acids, essential fatty acids, terpenes; mineral salts [3] [7]. In addition, pharmacological studies carried out on this plant have shown that it has anti-inflammatory [8]; antimicrobial [9]; antioxidants [4] and aphrodisiac properties [6]. Notwithstanding the widespread use of the aqueous extract from the seeds of Aframomum daniellii in traditional medicine, no systematic toxicological study has been undertaken in any species of this genus. Then, the aim of the present study was to evaluate the acute and reproductive toxicity of the aqueous extract of dry seeds of Aframomum daniellii on albino rats of the Wistar strain.

\section{Materials and Method}

\subsection{Collection of Plant Material}

The plant material consisted of the dry seeds of Aframomum daniellii ( $A$. daniellii) fruit, which was harvested in Bafoussam $\mathrm{I}$, in the western region of $\mathrm{Ca}$ meroon. The plant species was authenticated at the Cameroon National Herbarium in comparison with the sample $\mathrm{N}^{\circ} 40010$. The fruits were dried out of the sun and then crushed with a blender. The resulting powder was stored at room temperature $\left(25^{\circ} \mathrm{C}\right)$ until extraction.

\subsection{Preparation of the Aqueous Extract}

About $460 \mathrm{~g}$ of seed powder of $A$. daniellii (Figure 1(a)) was macerated in $5 \mathrm{~L}$ of distilled water with occasional shaking every $4 \mathrm{~h}$ for 2 days. Filtration was subsequently carried out with Whatman $n^{\circ} 3$ paper and the resulting filtrate (Figure 1 (b)) was oven dried at $45^{\circ} \mathrm{C}$. The brown dried extract obtained was approximately 


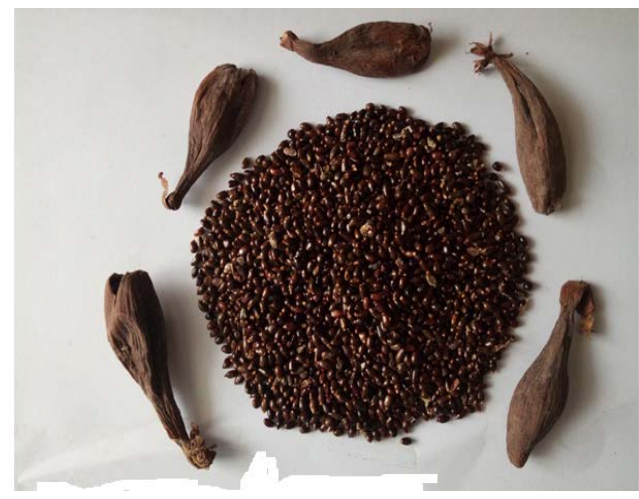

(a)

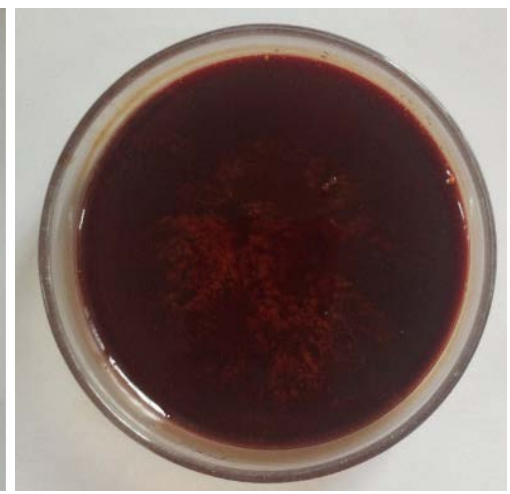

(b)

Figure 1. Photograph of fruits and dried seeds of Aframomum daniellii obtained after drying fresh fruit (a) and dry extract of Aframomum daniellii dry seeds (b) (Nde, 2019).

$64 \mathrm{~g}(16 \%)$. The obtained dried extract was diluted and stored in the refrigerator at $-4^{\circ} \mathrm{C}$ until usage. The preparation of the aqueous extract solution was done according to the physician's receipt. The treatment of rats requires the daily intake of a glass of aqueous extract from the seeds of $A$. daniellii which corresponds to $200 \mathrm{mg} / \mathrm{kg}$ for an adult. Two other doses $(100 \mathrm{mg} / \mathrm{kg}$ and $400 \mathrm{mg} / \mathrm{kg}$ ) were considered in this study.

\subsection{Chemicals and Reagents}

Clomifen citrate, ketamine, diazepam from Sigma-Aldrich (MO, USA).

\subsection{Experimental Design}

Wistar albino rats of approximately 10 - 12 weeks of age weighing between 180 $200 \mathrm{~g}$ were used. They were housed at the vivarium of the Faculty of Sciences of the University of Douala with natural light: dark cycle (12 h: $12 \mathrm{~h})$ at room temperature and fed with standard diet and free access to water. All the experiments were approved by the Ethic Committee of the University of Douala in accordance with the guidelines of European Community ( ${ }^{\circ} 2452$, CEI-Udo/08/2020/T). 45 female rats were distributed as follows:

- Group $1(\mathrm{n}=9)$ treated with distilled water $(10 \mathrm{~mL} / \mathrm{kg})$, represented neutral control;

- Group $2(\mathrm{n}=9)$ treated with clomiphene citrate at dose of $600 \mu \mathrm{g} / \mathrm{kg}$, represented positive control;

- Groups 3, 4 and 5 ( $\mathrm{n}=9$ each) treated with the aqueous extract of the dry seeds of Aframomum daniellii at doses of 100, 200 and $400 \mathrm{mg} / \mathrm{kg}$ respectively, represented the test groups.

The animals daily received oral administration of the different solutions for 14 days concomitantly.

On the $6^{\text {th }}$ day of administration of the products, the rats from each group were divided into subgroups of 2 rats. In each subgroup was introduced a rat of proven fertility during the last 8 days of treatment with a ratio of one male rat with two 
female rats. On the $1^{\text {st }}$ day of mating, the sexual behavior of the rats was observed for 6 hours (7a.m. to 1p.m.). Normally, after mating, female rats usually give birth at day between the $22^{\text {nd }}$ and $30^{\text {th }}$, since the gestational period in rats is 21 to 22 days [10]. By laparotomy, 16 days after fertilization (materialized by the formation of the vaginal plug), under anesthesia with diazepam $(10 \mathrm{mg} / \mathrm{kg} / \mathrm{im})$ and ketamine $(50 \mathrm{mg} / \mathrm{kg} / \mathrm{im})$, the implantation and resorption sites were counted in the uterine horn, as well as the number of corpora lutea and ovulation on the ovaries. On the same day, 4 of 9 rats were euthanized and blood samples were collected for hormonal assay. After laparotomy, the number of pregnant females was noted and the reproductive parameters was determined (percentage of gestation, fecundity, fertility, implantation, number of resorption) over two time intervals, from the $22^{\text {nd }}$ to the $30^{\text {th }}$ day and from the $31^{\text {st }}$ to the $60^{\text {th }}$ day for delayed births. After parturition, the fetuses were counted and cleaned. Many parameters were thus evaluated, namely:

- The number of resorption $=($ Number of implantation sites - Number of pups at birth);

- $\quad$ The implantation rate $=\frac{\text { Number of implantation sites }}{\text { Number of corpora lutea }} \times 100$;

- The resorption index $=\frac{\text { Total number of resorption sites }}{\text { Total number of implantation sites }} \times 100$; Pre-implantation loss

- $=\frac{\text { (Number of corpora lutea }- \text { Number of implantation sites) }}{\text { Number of corpora lutea }} \times 100$; Post-implantation loss

- $=\frac{\text { (Number of implantation sites }- \text { Number of live pups at birth })}{\text { Number of implantation sites }} \times 100 \quad$ [11].

The percentages (\%) of fertility, fecundity and prolificacy were also determined from the number of pregnant females, live pups and live pups using the formulas below [12] [13]:

- $\%$ fertility $=($ Number of pregnant females $) /($ Number of mated females $) \times$ 100

- $\%$ fecundity $=($ Number of live pups at birth $) /($ Number of mated females $) \times$ 100

- $\%$ of prolificacy $=($ Number of live pups at birth $) /($ Number of the litter $) \times 100$.

\section{Statistical Analysis of Data}

We statistically analyzed our data using the Graph Pad Prism version 8.01 software. These results were expressed as mean \pm Standard Error on Mean (S.E.M). The effect of the treatment on the quantified parameters was evaluated with ANOVA (Variances Analysis) one-way ANOVA. When the ANOVA result was significant, the Bonferroni post-test was used to locate the origin of the meaning. The average values of the test groups were compared with those of the different controls. A probability of less than $5 \%$ was considered significant. 


\section{Results}

\subsection{Effects of a Single Dose of Aqueous Extract of $A$. daniellii in Rats}

\subsubsection{Effects of a Single Dose of the Aqueous Extract of the Seeds of} A. daniellii in Rats

The acute toxicity study observed the behavior of the animals during the first 4 hours after gavage. The behavioral parameters observed were: locomotion, drowsiness and grooming. The comparison was made between the control group (group receiving distilled water) and the test group (group receiving the plant extract at a dose of $2000 \mathrm{mg} / \mathrm{kg}$ ), it emerges that: the test group exhibited immobility at the $1^{\text {st }}$ and at the $3^{\text {rd }}$ hour compared to the control group which was mobile. Regarding drowsiness, it was observed from the $3^{\text {rd }}$ to the $4^{\text {th }}$ hour in the test group compared to the control group, which exhibited permanent drowsiness during the observation time. From the first hour, grooming was observed in all the treated groups. But from the $2^{\text {nd }}$ hour, it was only observed in the group treated with plant extract at a dose of $2000 \mathrm{mg} / \mathrm{kg} / \mathrm{po}$ as well as in the control group.

\subsubsection{Effects of a Single Dose of the Aqueous Extract of $A$. daniellii on the Body Mass of Rats}

It can be seen from Table 1 that the body weight of the animals varied not significantly during the 14 days of observation, in the group receiving the extract of $A$. daniellii when compared to the group receiving distilled water (neutral control).

\subsubsection{Effects of a Single Dose of Aqueous Extract of $A$. daniellii on the Relative Weight of Some Organs}

The administration of a single dose of the aqueous extract of the seeds of $A$. daniellii did not cause any significant variation in the relative weight of organs such as the liver, kidneys and lung compared to the neutral control (Table 2).

Table 1. Evolution of the body weight of rats (g).

\begin{tabular}{ccccc}
\hline Treatments & $\mathrm{D}_{1}$ & $\mathrm{D}_{5}$ & $\mathrm{D}_{10}$ & $\mathrm{D}_{14}$ \\
\hline Distilled water & $128 \pm 5$ & $141 \pm 3$ & $150 \pm 2$ & $151 \pm 3$ \\
A. daniellii $(2000 \mathrm{mg} / \mathrm{kg})$ & $130 \pm 5$ & $148 \pm 8$ & $150 \pm 9$ & $158 \pm 10$ \\
\hline
\end{tabular}

Values represent means $\pm \mathrm{SEM} ; \mathrm{n}=3 ;$ A. daniellii $=$ Aframomum daniellii; $\mathrm{D}_{1}=$ day $1 ; \mathrm{J}_{5}=$ day $5 ; \mathrm{J}_{10}=$ day $10 ; \mathrm{J}_{14}=$ day 14

Table 2. Effects of the aqueous extract of the seeds of $A$. daniellii on the relative weights of some organs.

\begin{tabular}{ccccc}
\hline Treatments & Liver & Lungs & left kidney & right kidney \\
\hline Distilled water & $4.16 \pm 0.06$ & $0.83 \pm 0.04$ & $0.35 \pm 0.01$ & $0.32 \pm 0.01$ \\
A. daniellii $(2000 \mathrm{mg} / \mathrm{kg})$ & $4.65 \pm 0.32$ & $1.29 \pm 0.22$ & $0.39 \pm 0.02$ & $0.4 \pm 0.01$ \\
\hline
\end{tabular}

Values represent means $\pm \mathrm{SEM} ; \mathrm{n}=3 ;$ A. daniellii $=$ Aframomum daniellii. 


\subsubsection{Determination of Mortality Rate and Lethal Dose $50\left(\mathrm{LD}_{50}\right)$}

Since no deaths were recorded among the treated animals, the calculated mortality rate was $0 \%$ (Table 3 ). Thus, based on the globally harmonized classification system (GHS) of OECD guideline number 423 , the $\mathrm{LD}_{50}$ of the aqueous extract of the seeds of $A$. daniellii was greater than $2000 \mathrm{mg} / \mathrm{kg}\left(\mathrm{LD}_{50}>2000 \mathrm{mg} / \mathrm{kg}\right)$. As a result, the extract was classified in category 5 of the said system as a substance of low toxicity.

\subsection{Toxicity of the Aqueous Extract of the Seeds of A. Daniellii on the Reproductive Parameters of the Rat}

\subsubsection{Effects of the Aqueous Extract of the Seeds of $A$. daniellii on the Sexual Behavior of Animals on the First Day of Mating}

Table 4 below shows the effects of the aqueous seed extract of $A$. daniellii on the sexual behavior of rats on the first day of mating. It emerges from this table that the observation of the rats during the first six hours of the first day of mating showed a lot of mounting, an absence of rejection, the adoption of lordosis reflexes in the rats treated with clomiphene citrate as well as with the extract at the doses tested relative to the control. The rats treated with the extract of $A$. daniellii accepted mounts, unlike the control rats.

\subsubsection{Effects of the Aqueous Extract of the Seeds of $A$. daniellii on the Reproductive Parameters of Rats on the $18^{\text {th }}$ Day after Mating}

Table 5 opposite shows that administration of the extract did not allow resorptions to be observed in an all 5 groups. The number of implantation was 0 respectively in the rats treated with clomiphene citrate and in the rats treated with the aqueous extract of the seeds of $A$. daniellii at doses of 100, 200 and 400 $\mathrm{mg} / \mathrm{kg}$ when compared to the control which was $252 \pm 12$. The rate of the preimplantation losses of rats which received clomiphene citrate as well as the all treated rats was very higher when compared to the neutral control (100 vs 78\%;) while the post-implantation losses was lowwhen compared to the neutral control (0 vs $1 \%)$

\subsubsection{Effects of A. daniellii on Yellow Body Distribution of Female Rats}

Table 6 opposite shows that the administration of the aqueous extract of $A$. daniellii did not cause a modification ( $\mathrm{p}>0.05)$ in the number of corpora lutea and consequently in the number of ovulation of the cells in different groups tested against the neutral control.

\subsubsection{Effects of the Aqueous Extract of the Seeds of $A$. daniellii on the Reproductive Parameters of Rats on the 30th Day after Mating} At the end of 30 days after mating, all neutral control rats gave birth. We counted 52 pups with an average of $9 /$ female. No parturition was noted in the rats given the extract of seeds of $A$. daniellii at different doses and clomiphene citrate, ie zero rats per female in these 4 groups. The differences in the number of offspring are very significant between group I, the test groups $(\mathrm{p}<0.001)$ and groups II, III, IV and V. The reproduction parameters in the 5 studied groups 
are presented in Table 7. After the first births, the mother rats and their young were removed in order to protect the young from cannibalism and to facilitate the mating of the remaining rats. Thus, the gestation, fertility and prolificacy rate was respectively $100 \%, 866.67 \%$ and $866.67 \%$ for the rats of group I. For the rats that received clomiphene citrate and those treated with the extract of A. daniellii at doses of 100, 200 and $400 \mathrm{mg} / \mathrm{kg}$, none of the 6 rats gave birth, the percentage of gestation, fecundity and prolificacy was respectively $0 \%$ (Table 7).

Table 3. Change in mortality percentage 48 hours after administration of a single dose of aqueous extract of $A$. daniellii.

\begin{tabular}{ccccc}
\hline Treatments & Number of rats per group at the start & Number of dead rats & Proportion & Mortality (\%) \\
\hline Distilled water & 3 & 0 & $0 / 3$ & 0 \\
A. daniellii $(2000 \mathrm{mg} / \mathrm{kg})$ & 3 & 0 & $0 / 3$ & 0 \\
Total & 6 & 0 & $0 / 6$ & 0 \\
\hline
\end{tabular}

Table 4. Observation of the sexual behavior of rats for 6 hours on the 1st day of mating.

\begin{tabular}{|c|c|c|c|c|c|}
\hline \multirow{3}{*}{ Observations } & \multicolumn{5}{|c|}{ Sexual behavior of rats on the 1st day of mating } \\
\hline & \multicolumn{5}{|c|}{ Treatments/doses } \\
\hline & $\begin{array}{l}\text { Distilled water } \\
1 \mathrm{~mL} / 100 \mathrm{~g}\end{array}$ & $\begin{array}{l}\text { C. clom } \\
600 \mu \mathrm{g} / \mathrm{kg}\end{array}$ & $\begin{array}{c}\text { A. daniellii } 100 \\
\mathrm{mg} / \mathrm{kg}\end{array}$ & $\begin{array}{c}\text { A. daniellii } 200 \\
\mathrm{mg} / \mathrm{kg}\end{array}$ & $\begin{array}{l}\text { A. daniellii } \\
400 \mathrm{mg} / \mathrm{kg}\end{array}$ \\
\hline Receptivity of rats with respect to males & No & Yes & Yes & Yes & Yes \\
\hline Rejection of males & Yes & No & No & No & No \\
\hline Lordosis reflex in rats & No & Yes & Yes & Yes & Yes \\
\hline
\end{tabular}

Number of male crossed: 15; Number of female crossed: 30; Male/female ratio: 1:2; A. daniellii: Aframomum daniellii; C. clom: clomiphene citrate.

Table 5. Variation in reproduction parameters of the Wistar rat under the effect of the aqueous extract of the seeds of $A$. daniellii on the $18^{\text {th }}$ day after mating.

\begin{tabular}{|c|c|c|c|c|c|}
\hline \multirow{3}{*}{ Reproduction parameters } & \multicolumn{5}{|c|}{$18^{\text {th }}$ after mating: laparotomy } \\
\hline & \multicolumn{5}{|c|}{ Treatments/doses } \\
\hline & $\begin{array}{l}\text { Distilled water } \\
\quad 10 \mathrm{~mL} / \mathrm{kg}\end{array}$ & $\begin{array}{c}\text { C. clom } \\
600 \mu g / k g\end{array}$ & $\begin{array}{c}\text { A. daniellii } \\
100 \mathrm{mg} / \mathrm{kg}\end{array}$ & $\begin{array}{l}\text { A. daniellii } \\
200 \mathrm{mg} / \mathrm{kg}\end{array}$ & $\begin{array}{l}\text { A. daniellii } \\
400 \mathrm{mg} / \mathrm{kg}\end{array}$ \\
\hline Number of mated rats & 6 & 6 & 6 & 6 & 6 \\
\hline Number of resorption & $0 \pm 0$ & $0 \pm 0$ & $0 \pm 0$ & $0 \pm 0$ & $0 \pm 0$ \\
\hline Implantation rate $(\%)$ & $252 \pm 12$ & $0 \pm 0$ & $0 \pm 0$ & $0 \pm 0$ & $0 \pm 0$ \\
\hline Pre-implantation loss (\%) & $78 \pm 26$ & $100 \pm 0$ & $100 \pm 0$ & $100 \pm 0$ & $100 \pm 0$ \\
\hline Post-implantation loss (\%) & 1 & ND & ND & ND & ND \\
\hline
\end{tabular}

Values represent means \pm SEM; $\mathrm{n}=5$; Number of male crossed: 10; Number of female crossed: 30; Male/female ratio: 1:2; E. distilled: distilled water; $A$. daniellii: Aframomum daniellii; ND: not determined; C. clom: clomiphene citrate. Fertilization was materialized by the appearance of the cervical plug after crossing with males. 
Table 6. Effects of A. daniellii on yellow body distribution of female rats.

\begin{tabular}{|c|c|c|c|c|c|}
\hline \multirow{3}{*}{ Reproduction parameters } & \multicolumn{5}{|c|}{ 18th after mating: laparotomy } \\
\hline & \multicolumn{5}{|c|}{ Treatments/doses } \\
\hline & $\begin{array}{l}\text { Distilled water } \\
1 \mathrm{~mL} / 100 \mathrm{~g}\end{array}$ & $\begin{array}{l}\text { C. clom } \\
600 \mu \mathrm{g} / \mathrm{kg}\end{array}$ & $\begin{array}{l}\text { A. daniellii } \\
100 \mathrm{mg} / \mathrm{kg}\end{array}$ & $\begin{array}{l}\text { A. daniellii } \\
200 \mathrm{mg} / \mathrm{kg}\end{array}$ & $\begin{array}{l}\text { A. daniellii } \\
400 \mathrm{mg} / \mathrm{kg}\end{array}$ \\
\hline Number of mated rats & 6 & 6 & 6 & 6 & 6 \\
\hline Number of ovulation & $5 \pm 0.2$ & $8 \pm 1.23$ & $7 \pm 1$ & $5 \pm 0.49$ & $6 \pm 1.2$ \\
\hline Number of corpora lutea & $5 \pm 0.2$ & $8 \pm 1.23$ & $7 \pm 1$ & $5 \pm 0.49$ & $6 \pm 1.2$ \\
\hline
\end{tabular}

Values represent means \pm SEM; $\mathrm{n}=5$; Number of male crossed: 10; Number of female crossed: 30; Male/female ratio: 1:2; A. daniellii: Aframomum daniellii; C. clom: clomiphene citrate. Fertilization was materialized by the appearance of the cervical plug after crossing with males.

Table 7. Variation in reproductive parameters of the rat under the effect of the aqueous extract of the seeds of $A$. daniellii on the $30^{\text {th }}$ day after mating.

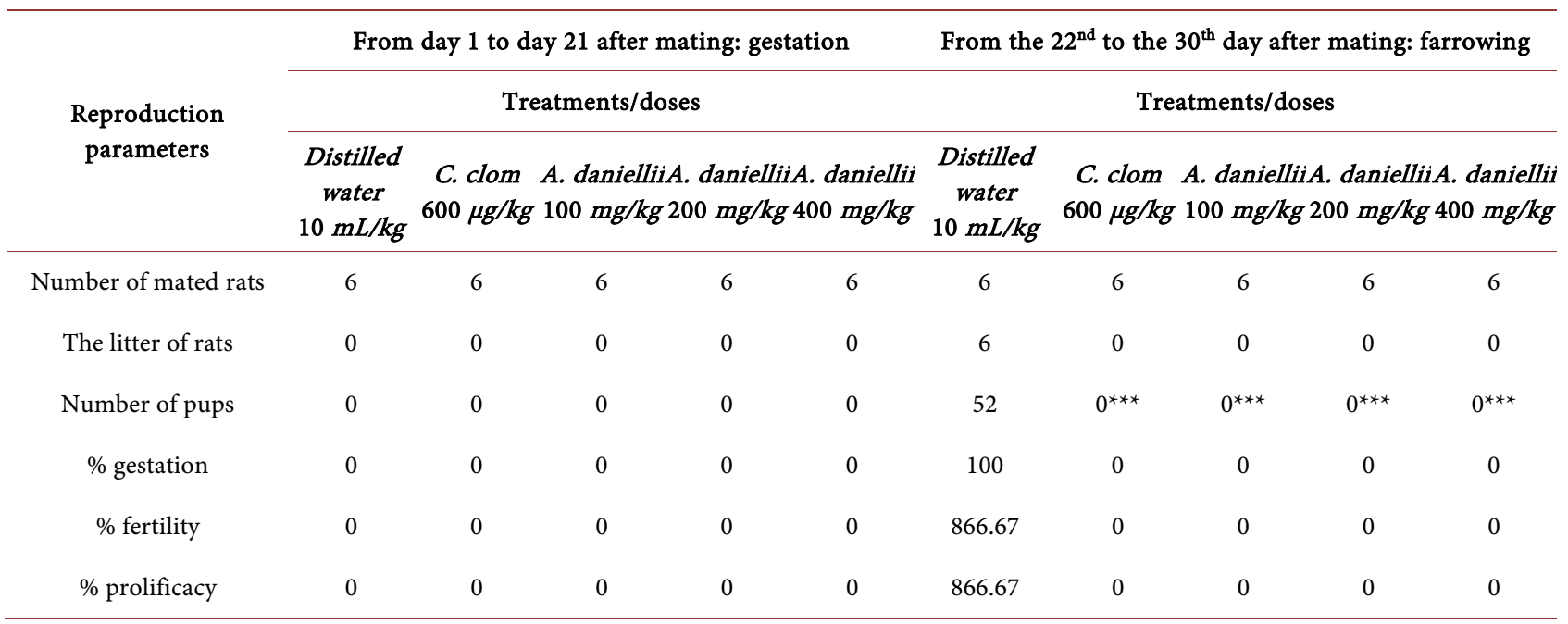

The values are represented as means \pm SEM, $n=6 ;{ }^{* *}: \mathrm{p}<0.001$ compared to the neutral control group; Number of male crossed: 10 ; Number of female crossed: 30; Male/female ratio: 1:2; A. daniellii: Aframomum daniellii; C. clom: clomiphene citrate. Fertilization was materialized by the appearance of the cervical plug after crossing with males.

\subsubsection{Effects of Aqueous Extract of $A$. daniellii on Serum Estrogen Concentration in Rats}

Figure 2 shows the effects of the aqueous extract of the dry seeds of $A$. daniellii on the concentration of estrogen in the serum of rats. It emerges from this figure that the administration of the extract at the respective doses of 100, 200 and 400 $\mathrm{mg} / \mathrm{kg} / \mathrm{po}$ resulted in a significant increase $(\mathrm{p}<0.001)$ in the serum estrogen level when compared to the neutral control which received distilled water (group I). Serum estrogen levels were also significantly increased in clomiphene citrate rats when compared to group I.

\section{Discussion}

The main objective of this work was to evaluate the acute and reproductive toxicity of the aqueous extract of dry seeds of Aframomum daniellii in albino rats of the Wistar strain. 


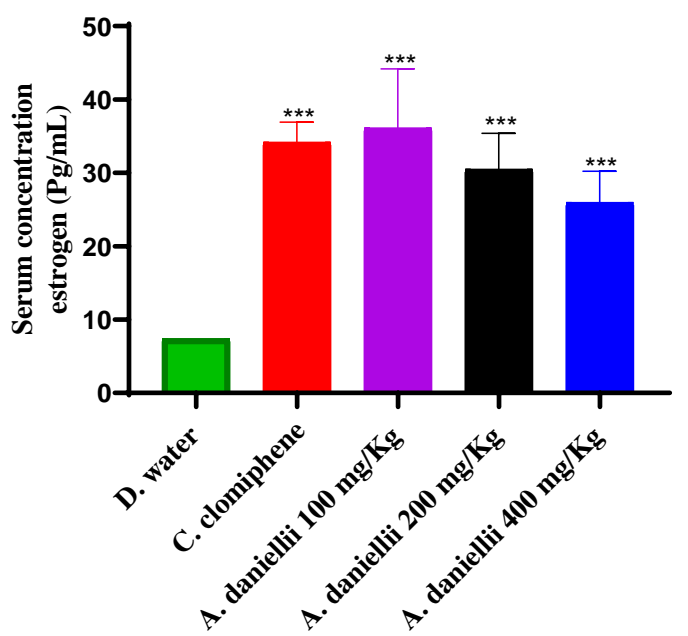

Figure 2. Effects of aqueous extract of $A$. daniellii on serum estrogen level in intact rat gonads. Each bar represents the mean \pm E.S.M; $\mathrm{n}=4{ }^{* * *}: \mathrm{p}<0.001$ (significant difference compared to the neutral control); A. daniellii: Aframomum daniellii; C. clomiphene: clomiphene citrate; D. distilled: distilled water.

Indeed, one of the major problems with the use of the herbal medicinal preparations is the lack of scientific and clinical data supporting the understanding of their efficacy and safety [14]. Contrary to beliefs that, medicinal plants are natural and devoid of any toxic effects, the use of certain plant extracts may pose risks to human, animal and/or environmental health [15]. Thus, the assessment of the threshold for plant extracts for medicinal or nutritional use is nowadays a mandatory step in the valuation and validation of the use of natural substances. Thus, an oral toxicity study was carried out on the aqueous extract of the seeds, following acute treatment. In this study, the oral lethal $50\left(\mathrm{LD}_{50}\right)$ dose 48 hours after administration of a single dose of the aqueous extract of $A$. daniellii was estimated to be greater than $2000 \mathrm{mg} / \mathrm{kg} / p o$. This value of the $\mathrm{LD}_{50}$ made it possible to classify the aqueous extract of $A$. daniellii in category 5 of the globally harmonized classification system for chemical substances, a category characterizing substances of low toxicity [15].

The administration of a single dose of the aqueous extract of $A$. daniellii (2000 $\mathrm{mg} / \mathrm{kg} / \mathrm{po}$ ) did not cause any mortality, moreover it did not affect the behavior and the digestive pathophysiology of the animals tested. Behavioral traits such as locomotion, aggressiveness, sensitivity to touch greatly reduced 2 hours after treatment, then, was improved after 48 hours of observation. This same treatment did not affect the weight gain and the relative weight of the liver, lungs and kidneys after two weeks of post-treatment observation. These results suggest that the aqueous extract of $A$. daniellii is of low toxicity.

The aqueous extract of the seeds of $A$. daniellii is used in western Cameroon in the preparation of the local sauce so called "yellow sauce" or "Nah poh" in the local language [16]. The "yellow sauce" is a part of the culinary habits of the 
populations of western Cameroon and is consumed by both men and women. Since the aqueous extract of the seeds of $A$. daniellii showed prosexual effects in male rats [6] and showed no sign of toxicity in acute treatment in female rats, the toxicity of the aqueous extract of the seeds of $A$. daniellii in reproductive function in subchronic treatment was then carried out in female rats. In this part of the work, administration of the aqueous extract of $A$. daniellii and clomiphene citrate on the $6^{\text {th }}$ day of treatment stimulated sexual arousal in rats when compared to the control. Sexual arousal was evidenced by an absence of rejection from males, receptivity of female rats to male rats and adoption of lordosis reflexes facilitating mountings by rats. These observations indicate that the aqueous extract of $A$. daniellii would exhibit estrogenic effects. In fact, the estrogenic effect improves vaginal trophicity and promotes sexual intercourse, while the progestogen effect narrows the vaginal meatus and makes penetration difficult [17]. This result, which corroborates the estrogenic properties of $A$. daniellii, is in agreement with those of some authors [18] [19] who demonstrated a link between anti-fertilization mechanisms and the estrogen and/or progestogen properties of plant extracts.

The administration of the aqueous extract of $A$. daniellii, 5 days before mating and then for 9 days during mating, resulted in an impairment of reproductive parameters (decrease of number of corpora lutea, the absence of implantation and resorption sites and consequently the absence of rate of gestation, fertility and prolificity) when compared to the neutral control, after 30 days of waiting for the giving birth. The gestation rate was $0 \%$ respectively for rats treated with clomiphene citrate and aqueous extract of $A$. daniellii at doses of 100, 200 and $400 \mathrm{mg} / \mathrm{kg} /$ po when compared to the neutral control where the rate was $100 \%$. These results would be attributed to the presence of bioactive compounds found in steroids, alkaloids, and saponins and present in the extract. These bioactive compounds are known for their contraceptive and anti-fertile activities [20] [21].

Indeed, the exact mechanism of zygote implantation is complex and requires a balanced and perfect functioning between estrogen and progesterone [22] [23]. This fact is in relation with the work of Thibault et al. (1998) [17] who suggest that, the contraceptive effect of estrogen pills is linked to an excess or deficit of sex hormones, including an excess of estrogen against progesterone deficiency. In the present study, the large amounts of exogenous phytoestrogens from the aqueous extract of $A$. daniellii at different doses would have created an imbalance with the amount of progesterone secreted by the yellow bodies, which would have prevented implantations observed after laparotomy. Moreover, it is well established that, phytoestrogens could induce maturational and morphological abnormalities, and disruption of the estrous cycle and infertility [24]. This elevation of estrogen was attested by a significant increase $(\mathrm{p}<0.001)$ in estrogen levels in rats treated in the different doses with $A$. daniellii when compared to the neutral control. On the other hand, alkaloids could exert toxic properties on the fetus and by this way prevent its normal development [25]. Similarly, it is known 
that saponins have anti-fertile, abortive, anti-implantation properties [20] [21]. Moreover, Saponins also possess the anti-proliferative properties of cells [26]. So, all these constituents could act individually or in synergy to affect the uterus and carry their anti-fertile effects. It is then clear that, the presence of these contraceptive compounds found in the aqueous extract of $A$. daniellii would have not made the proper development of fetuses easier in the uterine horns. However, further investigations are needed, in order to find the active compounds of these secondary metabolites (steroids, alkaloids, and saponins), responsible for this toxicity effects.

In the present work, administration of the aqueous extract of $A$. daniellii until the day of laparotomy showed no significant difference in the number of corpora lutea of the rats when compared to the neutral control. Similarly, despite good vaginal trophicity promoting sexual activity in rats, there was no implantation site in all treated rats with $A$. daniellii at the different doses. Consequently, in the absence of implantation, there is no resorption. Moreover, the presence of vaginal plug observed after mating in the rats treated with $A$. daniellii aqueous extract proves that there was fertilization to female rats. These results demonstrate that the infertility problems occurred to the rats after administration of the aqueous extract of $A$. daniellii would not be at the level of the development of the ovarian follicles, because, the estrogen level increased in the serum of the rats, nor at the level of the secretion of LH because corpora lutea were observed in the ovaries. Then, the administration of the aqueous extract of $A$. daniellii would therefore not inhibit the secretion and release of gonadotrophins by the pituitary gland. One can conclude that, the aqueous extract of $A$. daniellii would have inhibited the implantation of zygote, and then, acted as an anti-progesterone

\section{Conclusion}

In conclusion, the use of the aqueous extract of the seeds of $A$. daniellii shows that it is weakly toxic in acute treatment up to $2000 \mathrm{mg} / \mathrm{kg} / p o$. The aqueous extract of $A$. daniellii administered at the doses tested (100, 200 and $400 \mathrm{mg} / \mathrm{kg} / \mathrm{po}$ ) in normal reproducing rats showed a contraceptive and anti-progestin effect resulting in an absence of implantation and therefore in absence of gestation, prolificacy and fertility.

\section{Conflicts of Interest}

The authors declare no conflicts of interest regarding the publication of this paper.

\section{References}

[1] Abondo, R. and Amvam, Z.P. (1991) Valorisation des plantes aromatiques du genre Aframomum du Cameroun. Pharmocopée et médécine traditionelle africaine, 8188 .

[2] Kwazou, N., Dongmo, P., Tatsadjieu, N.L. and Samaza, M. (2009) Propriétés anti- 
fongiques des huiles essentielles de quelques plantes du genre Aframomum de Cameroun contre Aspergilus flavus. Cameroon Journal of Experimental Biology, 5, No. 1. https://doi.org/10.4314/cajeb.v5i1.44456

[3] Tané, P., Simplice, D., Tatsimo, G.A., Ayimele, Joseph, D. and Connolly (2005) Bioactive Metabolites from Aframomum Species. 11 th NAPRECA Symposium Book of Proceedings, Antananarivo, 9-12 August 2005, 214-223.

[4] Nguele, L.R., Fokunang, C.N., Etoundie, C., Chakokan, R.M., Ngondi, J.L., Tembe, E.A., Kechia, F., Ngameni, B., Gatsing, D. and Eyong, J.O. (2016) Utilisation des espèces du genre Aframomum (Aframomum aulacocorpus, A. citratum, A. daniellii) pour le contrôle du poids, le profil lipidique et le statut antioxydant chez les rats Wistar nourris avec une diète athérogène. International Journal of Biological and Chemical Sciences, 10, 2575-2586. https://doi.org/10.4314/ijbcs.v10i6.14

[5] Kemka, N.X., Deeh, D.B., Wankeu-Nya, M., Ngadjui, E., Kamanyi, A., Kamtchouing, P. and Watcho, P. (2019) Preventive Effects of Aframomum melegueta Extracts on the Reproductive Complications of Propylthiouracil-Induced Hypothyroidism in Male Rat. Andrologia, 51, e13306.

[6] Nde, Z., Massoma, L.D., Wankeu-Nya, M., Ngaha, M.I., Koloko, B.L., Bend, E., Etaga, N., Mbock, A., Toham, Y., Mboumwa, P.V. and Nyonseu, N.D. (2020) Potential Activity of Aframomum daniellii (Zingiberaceae) Dry Seeds: A Case Study of Its Action Mechanism on the Wistar Rat Strain with Testicular Deficiency. Biomedicine \& Pharmacotherapy, 131, Article ID: 110759.

https://doi.org/10.1016/j.biopha.2020.110759

[7] Bouba, A.A. (2009) Contribution à l'étude du développement d'un aliment fonctionnel à base d'épices du Cameroun: Caractérisation physico-chimique et fonctionnelle. Alimentation et Nutrition. Institut National Polytechnique de Lorraine. Français. NNT: 2009INPL006N. tel-01747196.

[8] Odukoya, O.A., Houghton, P.J. and Raman, A. (1999) Lipoxygenase Inhibitors in the Seeds of Aframomum danielii. Phytomedecine, International Journal of Phytotherapy and Phytopharmacology, 6, 251-256.

[9] Fasoyiro, S.B. and Adegoke, G.O. (2007) Phytochemical Characterization and the Antimicrobial Property of Aframomum daniellii Extract. African Journal of Agricultural Research, 2, 76-79.

[10] Gayrard, V. (2007) Physiologie de la reproduction des mammifères. 198 p.

[11] Costa-Silva, J.H., Lyra, M.M.A., Lima, C.R., Arruda, V.M., Araujo, A.V., Ribeiro, A., Arruda, A.C., Fraga, M.C., Lafayette, S.S. and Wanderley, A.G. (2007) A Toxicologial Evaluation of the Effect of Carapa guinensis Aubelt on Pregnancy in Wistar Rats. Journal of Ethnopharmacology, 112, 122-126.

https://doi.org/10.1016/j.jep.2007.02.004

[12] Peneme, B.M.L., Etou, O.A.W., Ondele, R., Nsonde, N.F.G., Elion, I.R.D., Akassa, H. and Abena, A.A. (2018) Effets sur les paramètres de reproduction de la ratte de deux plantes présumées contraceptives et leurs activités anti oxydantes. International Journal of Multidisciplinary and Current Research, 6, 1305-1311.

[13] Boly, H., Peneme, B.M., Sawadogo, L., Sulon J., Beckers, J.F. and Leroy, P.L. (2000) Effet dose-réponse de la Gonadotrophine (PMSG) sur la reproduction des brebis Djalonké de variété mossi. Tropicultura, 18, 126-129.

[14] Saidu, Y., Bilbis, L.S., Isezue, S.A., Hassan, S.W. and Abbas, A.Y. (2007) Acute and Subchronic Toxicity Studies of Crude Aqueous Extract of Albizzia chevalieri Harms (Leguminosae). Asian Journal of Biochemestry, 2, 224-236.

https://doi.org/10.3923/ajb.2007.224.236 
[15] OECD (2001) Harmonized Integrated Hazard Classification System for Human Health and Environmental Effects of Chemical Substances. 247 p.

[16] Tchiégang, C. and Mbougueng, P.D. (2005) Composition des épices utilisées dans la préparation du Nah poh et du Nkui de l'Ouest Cameroun. Tropicultura, 23, 193 200.

[17] Thibault, C., Beaumon, F. and Levasseur, M.C. (1998) La reproduction des vertébrés. Éditions Masson, Paris, 300 p.

[18] Benie, T., Duval, J. and Thieulant, M.L. (2003) Effects of Some Traditional Plant Extracts on Rat Oestrous Cycle Compared with Clomid. Phytotherapy Research, 17, 748-755. https://doi.org/10.1002/ptr.1206

[19] Bayala, B., Tamboura, H., Pellicer, M.T., Zongo, D., Traoré, A., Ouedraogo, L., Malpaux, B. and Sawadogo, L. (2006) Effets oestrogéniques du macéré aqueux des feuilles de Holarrhena floribunda (G.Don) Dur chez la rate ovariectomisée. Biotechnologie, Agronomie, Société et environnement, 10, 39-50.

[20] Danda, P. and Patil, S. (2012) Evaluation of Saponins from Trigonella foenum graecum Seeds for Its Antifertility Activity. Asian Journal of Pharmaceutical and Clinical Research, 5, 154-157.

[21] Dande, P.R., Bonde, C. and Pandita, N. (2014) Evaluation of Saponins from Siesbania sesban L. Merr for Its Antifertility Effects in Female Albino Rats. World Journal of Pharmacy and Pharmaceutical Sciences, 3, 1039-1054.

[22] Marieb, E.N. (1999) Anatomie et Physiologie Humaines. Traduction de la $4^{\text {ième }}$ version américaine, $1204 \mathrm{p}$.

[23] Bolarinwa, B.F., Zassenhaus, S.P., Sara, V.T. and Caroline, C. (2004) Effets des œstrogènes au cours du cycle hormonal de fécondité: cycle long ovulation retardée. Medical Science, 81, 215-220.

[24] Burton, J.L and Wells, M. (2002) The Effect of Phytoestrogens on the Female Genital Tract. Journal of Clinical Pathology, 55, 401-407. https://doi.org/10.1136/jcp.55.6.401

[25] Yakubu, M.T. (2008) Effect of Cnidoscolouus aconitifoliuus (Miller) IM Johnston Leaf Extract on Reproductive Hormones of Female Rats. International Journal of reproductive BioMedicine, 6, 149-155.

[26] Dia, J. and Mumper, R.J. (2010) Plant Phenolic: Extraction, Analysis and Their Antioxidant and Anticancer Properties. Molecules, 15, 7313-7352. https://doi.org/10.3390/molecules15107313 